\title{
Nandrolone Measurement
}

National Cancer Institute

\section{Source}

National Cancer Institute. Nandrolone Measurement. NCI Thesaurus. Code C75377.

The determination of the amount of nandrolone present in a sample. 